\title{
Intraperitoneal ropivacaine or ropivacaine plus meperidine for laparoscopic gynecological procedures
}

\author{
Jinekolojik laparoskopik cerrahide intraperitoneal ropivakain ve ropivakain ile \\ meperidin kombinasyonu
}

Semra KARAMAN,' Seden KOCABAŞ, ' Sedat ERGUN,' Vicdan FIRAT,' Meltem UYAR, ${ }^{2}$ Fatih ŞENDAĞ³

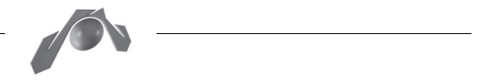

\begin{abstract}
Summary
Objectives: Postoperative pain after laparoscopic surgery is less intense than after laparotomy and patients may benefit from an intraperitoneal injection of local anesthetic and opioids. We aimed to compare intraperitoneal $0.75 \%$ ropivacaine with $0.75 \%$ ropivacaine plus meperidine for postoperative analgesia in patients undergoing gynecologic laparoscopy.

Methods: At the end of gynecologic laparoscopy, in a double-blind, randomized manner, one of the following injections was given intraperitoneally. Patients were allocated into three groups: Patients in R Group $(n=18)$ were given $0.75 \%$ ropivacaine $3 \mathrm{mg} / \mathrm{kg}$ in $200 \mathrm{~mL}$ saline; patients in RM Group ( $\mathrm{n}=17)$ were given meperidine $50 \mathrm{mg}$ plus $0.75 \%$ ropivacaine $3 \mathrm{mg} / \mathrm{kg}$ in $200 \mathrm{~mL}$ saline; patients in C Group ( $\mathrm{n}=18)$ were given $200 \mathrm{~mL}$ saline through the trocars. All patients were given diclofenac sodium when they had pain (VAS 3) and $1 \mathrm{mg} / \mathrm{kg}$ meperidine i.v. was also given when pain persisted.

Results: The pain scores and analgesic requirements during the first postoperative hour were significantly lower in the RM Group than those in the $\mathrm{R}$ and $\mathrm{C}$ Groups. Beyond that time, the pain scores were similar in all groups and there were no differences in total analgesic requirement in $24 \mathrm{~h}$ between groups. The three groups were comparable for shoulder pain and side effects.

Conclusion: The intraperitoneal infiltration of $0.75 \%$ ropivacaine plus meperidine reduced pain scores and analgesic requirement during the first one hour after gynecologic laparoscopy compared with the intraperitoneal infiltration of ropivacaine or saline.
\end{abstract}

Key Words: Intraperitoneal analgesia; laparoscopy; meperidine; ropivacaine.

\begin{abstract}
Özet
Amaç: Laparoskopik cerrabi sonrası postoperatif ağr laparatomiye göre daha hafiftir ve hastalar intraperitoneal lokal anestezik ve opioid uygulamalarından fayda görebilir. Çalısmamızda jinekolojik laparoskopik cerrabi uygulanacak hastalarda intraperitoneal uygulanan \% 0.75 'lik ropivakain ve meperidinle kombinasyonun postoperatif analjezi üzerine etkilerini karşılaştırmayı amaçladık.

Gereç ve Yöntem: Jinekolojik laparoskopi sonunda, randomize çift-kör çalı̧̧ma protokolüne göre intraperitoneal enjeksiyon uygulandı. Hastalar üç gruba ayrıldı: R Grubuna ( $n=18) \% 0.75$ 'lik ropivakain $3 \mathrm{mg} / \mathrm{kg} 200 \mathrm{ml}$ salin içinde; RM Grubuna ( $n=17)$ $\% 0.75$ 'lik ropivakain $3 \mathrm{mg} / \mathrm{kg}$ ve meperidin $50 \mathrm{mg} 200 \mathrm{ml}$ salin içinde; K Grubuna $(n=18) 200 \mathrm{ml}$ salin trokarla uygulandr. Hastalara ağrısı olduğunda (VAS 3) diklofenak sodyum ve eğer ağrısı geçmezse $1 \mathrm{mg} / \mathrm{kg}$ meperidin i.v. uyguland.

Bulgular: Ağrı skorları ve analjezik gereksinimi postoperatif ilk bir saat için RM grubunda daha düşük bulundu. Daba sonraki dönemde ă̆rı skorları tüm gruplar için benzerdi ve 24 saatlik total analjezik tüketimi açısından fark saptanmadı. Her üç grup arasinda omuz ağrisı ve yan etkiler yönünden fark saptanmad.

Sonuçः Jinekolojik laparoskopik cerrabi sonrast intraperitoneal \% 0.75 'lik ropivakain ile meperidin kombinasyonu ropivakain ya da saline göre postoperatif ilk bir saatte daha düşük ağr skorları ve analjezik tüketimi să̆lamaktadır.

Anahtar sözcükler: Intraperitoneal analjezi; laparoskopi; meperidin; ropivakain.
\end{abstract}

Departments of ${ }^{1}$ Anesthesiology and Reanimation, ${ }^{2}$ Algology, ${ }^{3}$ Obstetrics and Gynecology,

Ege University Faculty of Medicine, İzmir, Turkey

Ege Üniversitesi Tıp Fakültesi, 'Anesteziyoloji ve Reanimasyon Anabilim Dalı, ${ }^{2}$ Algoloji Bilim Dalı, ${ }^{3}$ Kadın Hastalıkları ve Doğum Anabilim Dalı, İzmir

Submitted (Başvuru tarihi) 09.11.2010 Accepted after revision (Düzeltme sonrası kabul tarihi) 13.12.2010

Correspondence (Illetişim): Semra Karaman M.D. Ege Üniversitesi Tip Fakültesi, Anesteziyoloji ve Reanimasyon Anabilim Dall, İzmir, Turkey

Tel: +90 - 232 - 3902142 e-mail (e-posta): semra.karaman@ege.edu.tr 


\section{Introduction}

Laparoscopic surgery is associated with significantly less pain, earlier discharge from the hospital, and more rapid convalescence than equivalent procedures performed by mini-laparotomy. ${ }^{[1,2]}$ However, patients undergoing laparoscopic procedures do experience postoperative pain, especially in the upper and lower abdomen, back, and shoulder regions. ${ }^{[3,}$ ${ }^{4]}$ Collins et al., ${ }^{[5]}$ reported the incidence of postoperative abdominal pain after outpatient gynecologic diagnostic laparoscopy to be $61.8 \%, 71.4 \%$, and $55.1 \%$ immediately after surgery, at postoperative $24 \mathrm{~h}$ and $48 \mathrm{~h}$, respectively. The pain experienced by patients undergoing laparoscopic surgery has a visceral component, as a result of surgical handling and diafragmatic irritation by dissolved carbon dioxide and a somatic component due to the holes made in the abdominal wall for the trocars. ${ }^{[6]}$ Shoulder pain, which is associated with peritoneal insufflation, especially when shoulder houlders and an exaggerated Trendelenburg position have been used frequently complicates the postoperative period after laparoscopic surgery. ${ }^{[7]}$

The intraperitoneal (IP) administration of local anaesthetics (LA) in reducing the intensity of postlaparoscopic pain is a conflicting subject. Although some investigators have reported that the IP delivery of LA is an effective method of providing analgesia after laparoscopic surgery, ${ }^{[8,9]}$ other investigators have not been able to confirm the analgesic efficacy of IP LA. ${ }^{[10,11]}$ There are many studies on the use of IP bupivacaine and lidocaine for postoperative analgesia. Ropivacaine, an amide local anaesthetic that has similar efficacy to bupivacaine at a large dose, also leads to reduced systemic and cardiac toxicity. ${ }^{[12,13]}$

The peripheral analgesic effects of opioids have been investigated in a number of studies. ${ }^{[14-16]}$ Some investigators reported that the IP administration of morphine failed to provide analgesia after laparoscopy. ${ }^{[14]}$ Peach et al. ${ }^{[17]}$ reported no benefit from the IP instillation of ropivacaine plus meperidine. However, Colbert et al., ${ }^{[9]}$ reported that the combination of IP bupivacaine plus IP meperidine provides satisfactory pain relief after laparoscopic tubal ligation. These findings have not been confirmed in a larger clinical trial. The aim of this study was to investigate whether IP ropivacaine or a combination of IP ropivacaine and meperidine provide effective pain relief after gynecologic laparoscopy and to record the analgesic profiles.

\section{Material and Methods}

The study was approved by our ethics committee, and all patients gave their written, informed consent. Fifty-three patients with ASA physical status I-II (aged 18-50 years) scheduled to undergo laparoscopic gynecology were included in this prospective, randomized, placebo-controlled, and doubleblinded study. Criteria for exclusion were: psychiatric disease, allergic reactions to opioids or local anesthetics, previous history of opioid intake, morbid obesity and severe chronic disease. Patients were randomized according to a table of random numbers.

Patients were not premedicated. Anesthetic management was standardized. After insertion of an intravenous cannula and placement of routine intraoperative monitoring devices such as an electrocardiograph, pulse oximetry, capnograph and noninvasive blood pressure monitor, all patients breathed $100 \%$ oxygen before induction of anesthesia. Anesthesia was induced with $10 \mu \mathrm{g} / \mathrm{kg}$ atropin, $1 \mu \mathrm{g} / \mathrm{kg}$ remifentanil, $2 \mathrm{mg} / \mathrm{kg}$ propofol and $0.1 \mathrm{mg} / \mathrm{kg}$ vecuronium was given to facilitate endotrachael intubation. Anesthesia was maintained with $1-2 \%$ endtidal sevoflurane in $50 \% \mathrm{O}_{2}-\mathrm{N}_{2} \mathrm{O}$ and remifentanil infusion. Remifentanil infusion rate of $0.5 \mu \mathrm{g} / \mathrm{kg} /$ min was maintained for 5 minutes after induction, followed by $0.25 \mu \mathrm{g} \mathrm{kg} / \mathrm{min}$ until the last surgical suture. Vecuronium $0.02 \mu \mathrm{g} / \mathrm{kg}$ was used as necessary. Ventilation was adjusted to maintain end-tidal carbondioxide between 34 and $40 \mathrm{mmHg}$. Surgery was conducted in the lithotomy and Trendelenburg position. During laparoscopy, intraabdominal pressure was limited to $14 \mathrm{mmHg}$. All patients received metoclopramide $10 \mathrm{mg}$ i.v. during operation.

At the end of successful gynecologic laparoscopy, patients were allocated randomly to one of three groups: patients in $\mathrm{R}$ Group $(\mathrm{n}=18)$ were given $0.75 \%$ ropivacaine $3 \mathrm{mg} / \mathrm{kg}$ in $200 \mathrm{~mL}$ saline; patients in RM Group ( $\mathrm{n}=17$ ) were given meperidine 
$50 \mathrm{mg}$ plus $0.75 \%$ ropivacaine $3 \mathrm{mg} / \mathrm{kg}$ in $200 \mathrm{~mL}$ saline, and patients in C Group ( $\mathrm{n}=18)$ were given $200 \mathrm{~mL}$ saline intraperitoneally through the trocars. The anesthesiologist and the surgeon administering the solutions intraperitoneally through the trocars were not informed about the contents of the solution. Carbondioxide was then evacuated from the peritoneal cavity. Surgical wounds were not infiltrated with local anesthetic solution. Anesthesia was discontinued, and neuromuscular blockade was reversed with $0.05 \mathrm{mg} / \mathrm{kg}$ neostigmine and $0.01 \mathrm{mg} / \mathrm{kg}$ atropine at the end of surgery.

All patients were informed about the visual analog scale (VAS) on the day before operation. Postoperative intra-abdominal pain was assessed both at rest and on coughing at $30 \mathrm{~min}, 1 \mathrm{~h}, 2 \mathrm{~h}, 6 \mathrm{~h}, 12 \mathrm{~h}$, and $24 \mathrm{~h}$. The patients were asked to rate the severity of pain via VAS ranging from no pain $(0 \mathrm{~cm})$ to the worst possible pain $(10 \mathrm{~cm})$. A standard postoperative analgesic regimen was used in all patients, with non-steroidal anti-inflammatory drugs and meperidine. During the first $24 \mathrm{~h}$ postoperatively, all patients were given (up to every $8 \mathrm{~h}$ ) diclofenac sodium (Voltaren ${ }^{\oplus}$, Novartis, Swiss) $75 \mathrm{mg}$ im as necessary (VAS $\geq 3$ ). Meperidine (Aldolan ${ }^{\oplus}$, Gerot Pharmazeutika $\mathrm{GmbH}$, Austria) $1 \mathrm{mg} / \mathrm{kg}$ i.v. was also given when pain persisted. In the postoperative peri- od, the time to first analgesic administration and total diclofenac sodium and meperidine requirements were recorded. The presence of postoperative shoulder pain and side effects such as nausea, vomiting, headache, pruritus, urinary retention or shivering were recorded by an independent investigator blinded to the treatment groups.

Statistical analyses were performed using SPSS (SPSS for Windows Release 10.0) statistical package. The results are presented as mean \pm standard deviation, median (range), or frequencies as appropriate. Statistical analysis was performed with ANOVA and $p<0.05$ was considered statistically significant. The VAS values were compared between groups by using the Kruskal-Wallis test followed by the Wilcoxon Matched Pairs Rank test. The occurrence of postoperative side effects was compared between groups by using a $\chi^{2}$ test.

\section{Results}

In the RM Group, one patient who had conversion to open surgery did not complete the study and was excluded. The groups were similar with regard to age, height, weight, ASA classification, and duration of surgery (Table 1). There were no statistically significant differences among the groups regarding

Table 1. Patient characteristics and surgical data

\begin{tabular}{lccc}
\hline & Group R $(\mathbf{n}=\mathbf{1 8})$ & Group RM $(\mathbf{n}=\mathbf{1 7})$ & Group C (n= 18) \\
\hline Age $($ year) & $33.1 \pm 7.4$ & $33.8 \pm 6.7$ & $32.4 \pm 4.5$ \\
Weight $(\mathrm{kg})$ & $66.5 \pm 10.4$ & $64.1 \pm 11.4$ & $63.2 \pm 7.2$ \\
Height $(\mathrm{cm})$ & $161.6 \pm 5.2$ & $163.7 \pm 5.4$ & $162.3 \pm 4.8$ \\
ASA $(\mathrm{I} / \mathrm{II})$ & $11 / 7$ & $12 / 5$ & $12 / 6$ \\
Duration of surgery $(\mathrm{min})$ & $92.5 \pm 41.1$ & $98.2 \pm 36.5$ & $100.3 \pm 24.5$ \\
\hline
\end{tabular}

Values are mean \pm SD. There were no significant differences among groups.

Table 2. Surgical procedures

\begin{tabular}{lccc}
\hline & Group R (n= 18) & Group RM (n= 17) & Group C (n= 18) \\
\hline Salpingectomy (n/\%) & $2 / 11.1$ & $3 / 16.6$ & $2 / 11.1$ \\
Ovarian cystectomy (n/\%) & $8 / 44.4$ & $6 / 33.3$ & $8 / 44.4$ \\
Myomectomy (n/\%) & $4 / 22.2$ & $3 / 16.6$ & $3 / 16.6$ \\
LAVH (n/\%) & $4 / 22.2$ & $5 / 27.7$ & $5 / 27.7$ \\
\hline
\end{tabular}

LAVH: Laparoscopic-assisted vaginal hysterectomy. There were no significant differences among groups. 
Table 3. Analgesic requirements

\begin{tabular}{lccc}
\hline & Group R $(\mathbf{n}=\mathbf{1 8})$ & Group RM $(\mathbf{n}=\mathbf{1 7})$ & Group C $(\mathbf{n}=\mathbf{1 8})$ \\
\hline Diclofenac sodium in 1h $(\mathrm{mg})$ & $62.5 \pm 28.7$ & $35.2 \pm 31.5^{*}$ & $70.8 \pm 17.6$ \\
Diclofenac sodium in 24h $(\mathrm{mg})$ & $108.3 \pm 46.1$ & $88.2 \pm 29.4$ & $125 \pm 62.9$ \\
Meperidine in 24h $(\mathrm{n})$ & $4(22.2 \%)$ & $3(17.6 \%)$ & $8(44.4 \%)$ \\
\hline
\end{tabular}

Values are mean \pm SD or number of patients $n(\%) .{ }^{*} p<0.05$, Group RM versus Group R and Group C.

Table 4. Postoperative characteristics and side effects.

\begin{tabular}{lccc}
\hline & Group R (n= 18) & Group RM (n= 17) & Group C (n= 18) \\
\hline Nausea & $6(33.3 \%)$ & $7(38.8 \%)$ & $9(50 . \%)$ \\
Vomiting & $2(11.1 \%)$ & $2(11.1 \%)$ & $3(16.6 \%)$ \\
Shoulder pain & $9(50 \%)$ & $10(59 \%)$ & $11(61 \%)$ \\
\hline
\end{tabular}

Values are number of patients $\mathrm{n}(\%)$ or mean \pm SD. There were no significant differences among groups in the overall incidence of side effects.

the different types of surgical procedures (Table 2).

Pain scores were highest at $30 \mathrm{~min}$ after the laparoscopic procedure in all groups. There were no significant differences between the three groups with regard to pain scores (at rest or on coughing) throughout the study period except in the first postoperative hour. In the RM Group, pain scores at rest and on coughing were lower than those in the $\mathrm{R}$ and $\mathrm{C}$ Groups at postoperative $30 \mathrm{~min}$ and $1 \mathrm{~h}$ (Figure 1, 2).

At the end of the first postoperative hour, the amount of diclofenac sodium required was significantly lower in RM Group than in $\mathrm{R}$ and $\mathrm{C}$ groups (Table 3) ( $\mathrm{p}<0.05)$. The total amount of diclofenac sodium consumption in $24 \mathrm{~h}$ were similar in all groups

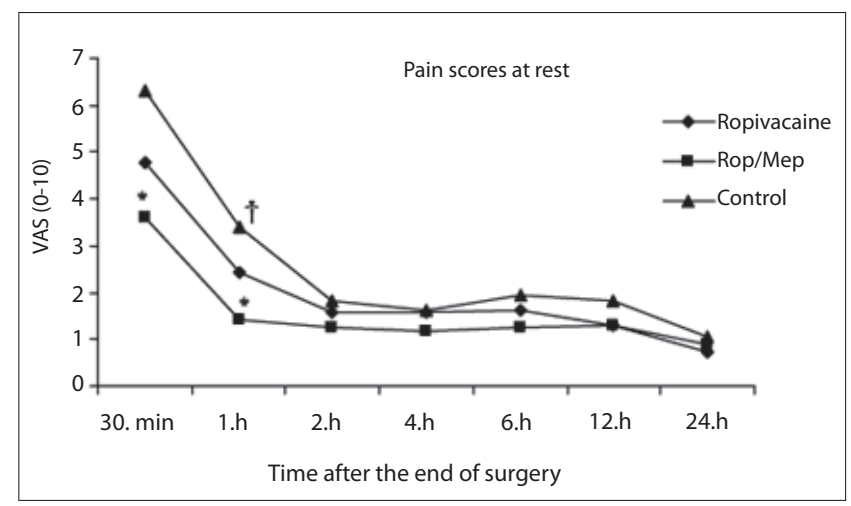

* $p<0.05$, Group RM versus Group C. $+p<0.05$, Group C versus Group RM and Group R.

Fig. 1. Pain scores at rest in each group at each of the time periods examined. Values are median.
(Table 3). The number of patients receiving meperidine treatment in the postoperative period were similar between groups (Table 3) ( $p>0.05)$.

No differences in the incidence of nausea, vomiting and shoulder pain were observed between R Group, RM Group and C Group ( $p>0.05$ ) (Table 4). There were no cases of shivering, headache, pruritus or urinary retention reported in any of the groups.

\section{Discussion}

The results of the present study suggest that the IP infiltration of ropivacaine/meperidine was more effective in reducing pain immediately after operative laparoscopy when compared with IP ropivacai-

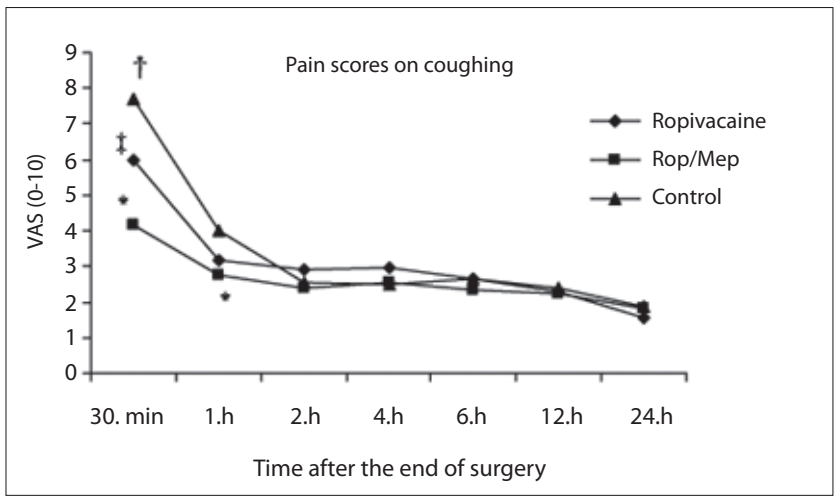

* $\mathrm{p}<0.05$, Group RM versus Group C. † p <0.05, Group C versus Group RM and Group $\mathrm{R}, \neq \mathrm{p}<0.05$, Group R versus Group RM.

Fig. 2. Pain scores on coughing in each group at each of the time periods examined. Values are median. 
ne alone or IP saline, but the effect was not seen beyond one hour. The pain scores and analgesic requirement in the RM Group were lower than those in the $\mathrm{R}$ and $\mathrm{C}$ groups during the first hour after surgery, but cumulative analgesic consumption in 24 $\mathrm{h}$ was similar in all groups. This suggests that, although IP injection of ropivacaine/meperidine has some effect on postoperative pain, it remains a weak analgesic technique.

Bisgaard et al., ${ }^{[18]}$ suggested that pain after laparoscopic cholecystectomy was divided into three components: incisional pain, which dominated over visceral pain, which in turn dominated over shoulder pain. Several investigators have reported that the visceral pain experienced after laparoscopic cholecystectomy can be theoretically blocked by IP infiltration. ${ }^{[19]}$ In the present study, IP infiltration with ropivacaine or ropivacaine plus meperidine was found to ineffective in preventing visceral pain after gynecologic laparoscopy beyond one hour. The results of the present study seem to be in accordance with the findings of Bisgaard et al., ${ }^{[18]}$ who reported that IP infiltration of local anaesthetics or opioids is ineffective in blocking incisional pain.

The efficacy of IP local anaesthetic infiltration has been demonstrated in numerous studies on laparoscopic cholecystectomy, but there is no consensus regarding the dose, concentration, site and manner of administration. ${ }^{[9,10,13,16]}$ Although the IP administration of bupivacaine 50-150 mg was found to be effective in preventing postoperative pain after laparoscopic cholecystectomy in some studies, ${ }^{[6,20]}$ there are others who reported IP bupivacaine to be inefficient for analgesia after laparoscopic cholecystectomy. ${ }^{[10,21]}$ Scheinin et al., ${ }^{[21]}$ reported that IP instillation of $0.15 \%$ bupivacaine $150 \mathrm{mg}$ at the end of surgery had no effect on pain after laparoscopic cholecystectomy. Joris et al., ${ }^{[10]}$ investigated the effects of administering $0.125 \%$ bupivacaine $(80 \mathrm{~mL})$ or saline $(80 \mathrm{~mL})$ intraperitoneally at the end of laparoscopic cholecystectomy. The investigators reported IP bupivacaine to be ineffective for treating pain after laparoscopic cholecystectomy.

In gynecologic laparoscopy, decreased postoperative pain scores after IP local anesthetic administration have been reported. ${ }^{[8,22,23]}$ Here as well, howe- ver, the mode of administration lacks standardization, e.g., infiltration on the trajectory of the trocars, infiltration of the uterine tubes, and peritoneal instillation before and after insufflation. Goldstein et al., ${ }^{[7]}$ reported that the IP instillation of $20 \mathrm{~mL}$ of either $0.5 \%$ bupivacaine or $0.75 \%$ ropivacaine prevented postoperative pain and decreased the need for postoperative analgesia, when compared with placebo in patients undergoing laparoscopic gynecologic surgery. Callesen et al., ${ }^{[23]}$ combined port site and mesosalpinx infiltration and peritoneal instillation by using $285 \mathrm{mg}$ of ropivacaine $(50 \mathrm{~mL})$ in a double-blinded, randomized, placebo-controlled study on 80 patients undergoing laparoscopic tubal sterilization. The investigators demonstrated significant improvement of pain scores over the first 8 $\mathrm{h}$ on coughing and during mobilization in the ropivacaine group when compared with the placebo group. In contrast with the studies mentioned above, we used relatively higher volumes of IP infiltration (3 mg/kg ropivacaine in $200 \mathrm{~mL}$ saline). Since there is a close relationship between the concentration of a local anaesthetic acting on a nerve and the degree of conduction blockade that occurs, failure of the technique in the present study could be due to the low concentration of ropivacaine. Higher volumes of IP local anaesthetic infiltration have also been used in some studies, such as the study by Maestroni et al., ${ }^{[24]}$ in which $5 \mathrm{mg} / \mathrm{kg}$ ropivacaine in $200 \mathrm{~mL}$ saline or placebo was administered intraperitoneally before creation of the pneumoperitoneum for laparoscopic cholecystectomy. The investigators found decreased postoperative pain scores with the preemptive administration of IP ropivacaine when compared with IP saline. In this study, unlike the study by Maestroni et al., ${ }^{[24]}$ where IP local anesthetic was given preemptively, $3 \mathrm{mg} / \mathrm{kg}$ ropivacaine was administered through the trocars into the peritoneal cavity at the end of surgery.

The opioid chosen for this study was meperidine, rather than morphine or fentanyl, because of the dual local anesthetic and analgesic properties of meperidine. The effects of meperidine appear to be produced by its actions on two independent pathways: the opioid receptor pathways, which subserve analgesic action, and the sodium channels, which subserve local anesthetic action. These local anesthetic actions appear to be independent of its opio- 
id analgesic activity when administered topically in the subarachnoid space, epidurally, or on exposed nerve in experimental studies. After IP administration, meperidine is absorbed from the peritoneal cavity and has a central analgesic action. The speed of absorption and the rapidity of onset of action when administered by this route are uncertain in patients undergoing laparoscopy. ${ }^{[9]}$ Colbert et al., ${ }^{[9]}$ reported that the combination of IP bupivacaine plus IP meperidine achieved adequate pain relief after laparoscopic tubal ligation. These authors suggested that the observed analgesia was probably produced by the local anesthetic effect of meperidine observed both in vitro and in vivo. In the present study, the lower pain scores and analgesic requirement in the RM Group than those in the R and C Groups during the first hour after surgery suggest that meperidine was effective as an opioid in preventing early postoperative pain.

Shoulder pain may occur in as many as $63 \%$ or as few as $35 \%$ of patients undergoing laparoscopic surgery. ${ }^{[3]}$ The prolonged presence of shoulder tip pain suggests excitation of the phrenic nerve. This pain is present often after laparoscopy associated with persistent pnemoperitoneum, sometimes for as long as three days. There is a statistically significant correlation between the width of the gas bubble and pain score, and this can be reduced by aspiration of the gas under the diaphragm, the use of a gas drain or application of local anaesthesia under the diaphgram under direct vision, through an irrigation device or through a sub-phrenic catheter. ${ }^{[3]}$ The incidence of shoulder pain was found to be $50-75 \%$ in the present study, where the gas under the diaphragm was repeatedly suctioned.

We did not observe any side-effects attributable to the local anesthetic, such as shivering, nausea, dizziness, confusion, seizures or cardiac arryhthmias. The plasma concentrations of local anesthetic were not measured, but the doses of ropivacaine used in our study were lower than those thought to cause systemic toxicity. Some reports have shown the range of mean plasma concentration to be $2.93-3.76 \mu \mathrm{g} / \mathrm{mL}$ after the IP administration of 150-300 mg plain ropivacaine. ${ }^{[19]}$ Maestroni et al. ${ }^{[24]}$ found the lowest plasma concentration of ropivacaine to be $0.35 \mu \mathrm{g} /$ $\mathrm{mL}$ at $15 \mathrm{~min}$ and the highest plasma concentrati- on of ropivacaine to be $2.2 \mu \mathrm{g} / \mathrm{mL}$ at $2 \mathrm{~h}$ after administering $5 \mathrm{mg} / \mathrm{kg}$ ropivacaine in $200 \mathrm{~mL}$ saline through the IP route in patients undergoing laparoscopic cholecystectomy. Labaille et al., ${ }^{[19]}$ reported no systemic toxicity after the IP administration of $300 \mathrm{mg}$ ropivacaine in patients undergoing laparoscopic cholecystectomy and similar to our study, no plasma concentrations were determined.

In summary, the IP infiltration of $7.5 \%$ ropivacaine plus meperidine reduced pain scores and analgesic requirement during the first one hour after gynecologic laparoscopy compared with the IP infiltration of ropivacaine or saline. Although the present study failed to show the efficacy of IP ropivacaine or ropivacaine plus meperidine in preventing postoperative pain beyond one hour, further research is needed to evaluate the timing and the localization of IP analgesia for gynecologic laparoscopy.

\section{References}

1. Barkun JS, Barkun AN, Sampalis JS, Fried G, Taylor B, Wexler $\mathrm{MJ}$, et al. Randomised controlled trial of laparoscopic versus mini cholecystectomy. The McGill Gallstone Treatment Group. Lancet 1992;340(8828):1116-9.

2. Smith I. Anesthesia for laparoscopy with emphasis on outpatient laparoscopy. Anesthesiol Clin North America 2001;19(1):21-41.

3. Alexander Jl. Pain after laparoscopy. $\mathrm{Br} J$ Anaesth 1997;79(3):369-78.

4. Mouton WG, Bessell JR, Otten KT, Maddern GJ. Pain after laparoscopy. Surg Endosc 1999;13(5):445-8.

5. Collins KM, Docherty PW, Plantevin OM. Postoperative morbidity following gynaecological outpatient laparoscopy. A reappraisal of the service. Anaesthesia 1984;39(8):819-22.

6. Pasqualucci A, de Angelis V, Contardo R, Colò F, Terrosu G, Donini $A$, et al. Preemptive analgesia: intraperitoneal local anesthetic in laparoscopic cholecystectomy. A randomized, double-blind, placebo-controlled study. Anesthesiology 1996;85(1):11-20.

7. Goldstein A, Grimault P, Henique A, Keller M, Fortin A, Darai E. Preventing postoperative pain by local anesthetic instillation after laparoscopic gynecologic surgery: a placebo-controlled comparison of bupivacaine and ropivacaine. Anesth Analg 2000;91(2):403-7.

8. Narchi $P$, Benhamou $D$, Fernandez $H$. Intraperitoneal local anaesthetic for shoulder pain after day-case laparoscopy. Lancet 1991;338(8782-8783):1569-70.

9. Colbert ST, Moran K, O'Hanlon DM, Chambers F, Moriarty DC, Blunnie WP. An assessment of the value of intraperitoneal meperidine for analgesia postlaparoscopic tubal ligation. Anesth Analg 2000;91(3):667-70.

10. Joris J, Thiry E, Paris P, Weerts J, Lamy M. Pain after laparoscopic cholecystectomy: characteristics and effect of intraperitoneal bupivacaine. Anesth Analg 1995;81(2):379- 
84

11. Raetzell M, Maier C, Schröder D, Wulf H. Intraperitoneal application of bupivacaine during laparoscopic cholecystectomy--risk or benefit? Anesth Analg 1995;81(5):967-72.

12. Stienstra R. The place of ropivacaine in anesthesia. Acta Anaesthesiol Belg 2003;54(2):141-8.

13. Knudsen K, Beckman Suurküla M, Blomberg S, Sjövall J, Edvardsson N. Central nervous and cardiovascular effects of i.v. infusions of ropivacaine, bupivacaine and placebo in volunteers. Br J Anaesth 1997;78(5):507-14.

14. Schulte-Steinberg $H$, Weninger $E$, Jokisch $D$, Hofstetter $B$, Misera A, Lange $V$, et al. Intraperitoneal versus interpleural morphine or bupivacaine for pain after laparoscopic cholecystectomy. Anesthesiology 1995;82(3):634-40.

15. Power I, Brown DT, Wildsmith JA. The effect of fentanyl, meperidine and diamorphine on nerve conduction in vitro. Reg Anesth 1991;16(4):204-8.

16. Armstrong PJ, Morton CP, Nimmo AF. Pethidine has a local anaesthetic action on peripheral nerves in vivo. Addition to prilocaine $0.25 \%$ for intravenous regional anaesthesia in volunteers. Anaesthesia 1993;48(5):382-6.

17. Paech MJ, Ilett KF, Hackett LP, Page-Sharp M, Parsons RW. Disposition and clinical outcome after intraperitoneal meperidine and ropivacaine administration during laparoscopic surgery. Anesth Analg 2008;106(1):278-86.

18. Bisgaard T, Klarskov B, Kristiansen VB, Callesen T, Schulze S,
Kehlet $\mathrm{H}$, et al. Multi-regional local anesthetic infiltration during laparoscopic cholecystectomy in patients receiving prophylactic multi-modal analgesia: a randomized, double-blinded, placebo-controlled study. Anesth Analg 1999;89(4):1017-24.

19. Labaille T, Mazoit JX, Paqueron X, Franco D, Benhamou D. The clinical efficacy and pharmacokinetics of intraperitoneal ropivacaine for laparoscopic cholecystectomy. Anesth Analg 2002;94(1):100-5.

20. Mraović B, Jurisić T, Kogler-Majeric V, Sustic A. Intraperitoneal bupivacaine for analgesia after laparoscopic cholecystectomy. Acta Anaesthesiol Scand 1997;41(2):193-6.

21. Scheinin B, Kellokumpu I, Lindgren L, Haglund C, Rosenberg $\mathrm{PH}$. Effect of intraperitoneal bupivacaine on pain after laparoscopic cholecystectomy. Acta Anaesthesiol Scand 1995;39(2):195-8.

22. Loughney AD, Sarma V, Ryall EA. Intraperitoneal bupivacaine for the relief of pain following day case laparoscopy. $\mathrm{Br} J \mathrm{Ob}-$ stet Gynaecol 1994;101(5):449-51.

23. Callesen T, Hjort D, Mogensen T, Schouenborg L, Nielsen D, Reventlid $\mathrm{H}$, et al. Combined field block and i.p. instillation of ropivacaine for pain management after laparoscopic sterilization. Br J Anaesth 1999;82(4):586-90.

24. Maestroni U, Sortini D, Devito C, Pour Morad Kohan Brunaldi F, Anania G, Pavanelli L, et al. A new method of preemptive analgesia in laparoscopic cholecystectomy. Surg Endosc 2002;16(9):1336-40. 